\title{
Alexander the Great Conqueror and Captive of Death: His Various Images in Byzantine Art
}

\section{George Galavaris}

Volume 16, numéro 1, 1989

\section{URI : https://id.erudit.org/iderudit/1073324ar}

DOI : https://doi.org/10.7202/1073324ar

\section{Aller au sommaire du numéro}

\section{Éditeur(s)}

UAAC-AAUC (University Art Association of Canada | Association d'art des universités du Canada)

\section{ISSN}

0315-9906 (imprimé)

1918-4778 (numérique)

\section{Découvrir la revue}

\section{Citer cet article}

Galavaris, G. (1989). Alexander the Great Conqueror and Captive of Death: His Various Images in Byzantine Art. RACAR : Revue d'art canadienne / Canadian Art Review, 16(1), 12-18. https://doi.org/10.7202/1073324ar

\section{Résumé de l'article}

La personnalité et les exploits d'Alexandre ont enchanté les écrivains, les poètes et les artistes. Ce phénomène a contribué à la création des divers images d'Alexandre dans l'art et la littérature byzantins. Les plus anciennes de ces images, remontant à l'Antiquité, sont celles du chasseur idéal, du héros, du bon prince.

Le Roman d'Alexandre, la poésie byzantine épique, les commentaires sur le livre de Daniel et autres textes des Péres de l'Église, par leurs illustrations et leurs oeuvres d'art apparentées, ont associe Alexandre aux héros de l'Antiquité et de l'Ancien Testament, le liant ainsi au monde chrétien. L'Ascension d'Alexandre, l'un des thèmes les plus populaires du cycle pictural du roman, étendit l'empire du Grand Conquérant aux cieux, tout en soulignant ses limites, celles d'un mortel.

Puis, aux époques byzantine tardive et post-byzantine, l'image d'Alexandre devint associée à un genre poétique traitant de l'éphémère humain. Selon une légende, le moine Sisoes découvra la tombe et les ossements d'Alexandre. C'est pourquoi Alexandre est représenté dans un sarcophage ou foulé aux pieds par Charon. Ces compositions sont populaires dans les fresques des Monastères du Mont-Athos et dans la peinture d'icône crétoise. Alexandre y symbolise la futilité de toute gloire terrestre.

Mais ces moines et ces poètes qui méditèrent sur la mort du héros et sur le destin de l'homme ne voulurent pas tout de même le voir disparaître dans un tombeau ou demeurer captif de la mort. Ainsi dans quelques icônes post-byzantines, Alexandre devient à la fois symbole de l'éphémère et de l'homme juste dont l'âme, à l'heure du trépas, est reçue par l'archange Michel. Son élévation au Paradis est le thème des légendes que l'on trouve dans la tradition littéraire traitant d'Alexandre.
Tous droits réservés (C) UAAC-AAUC (University Art Association of Canada | Association d'art des universités du Canada), 1989
Ce document est protégé par la loi sur le droit d'auteur. L'utilisation des services d'Érudit (y compris la reproduction) est assujettie à sa politique d'utilisation que vous pouvez consulter en ligne.

https://apropos.erudit.org/fr/usagers/politique-dutilisation/ 


\title{
Alexander the Great Conqueror and Captive of Death: His Various Images in Byzantine Art*
}

\author{
GEORGE GAI.AVARIS \\ Mc Gill University' \\ To Kurt Weitzmann
}

La persomalité et les exploits d' Alexandre ont enchante les écrivans. le's poètes et les antistes. (ie phenomène a comtribuc a lat creation des divers images d'Alexandre dams l'ant en la litterature byomtins. Les plus anciemnes de ces imatges. remomtant a l'intiefuite. sont celles du chasseur idcal. du héros. du bon prince.

le Roman d' Alexandre, la poésic byantine épicue, les commentaires sum le live de Inanicl co autres textes des Péres de l'Fglise. par leurs illustrations ed leurs oeures

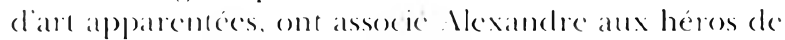
l'Anticpute et de l'Ancien lestament, le liant ainsi an monde chretien. L: Ascension d'Alexandre, l'un des thèmes les plus populaires du cycle pictural du roman, étendit l'empire du fiand Conquérant anx cieux, tout en soulighant se's limites, celles d'un mortel.

Puis. anx époques byantine tardive et postbyantinc, limage d'Alexandre devint associée à $u n$ genre poétique tratiant de léphémère humain. Selon unc légende, le moine Sisoes décourra la tombe eo les ossements d'Alexandre. ("est pourquoi Alexandre est représenté clans un sarcophage ou foulé aux piecls par (haron. Ces compositions sont populaires dians les fresques des Monastères du Mont-Athos et dans la peinture d'iconne crétoise. Alcxandre y stmbolise la futilité de toute gloire terrestre.

Mais ces moincs et ces pocics qui méditiont sur la mort du héros et sur le destin de l'homme ne voulurent pas tout de même le voir clisparaître dans un tombeau ou demeurer captif de la mort. Ainsi dans puclepues icones post-byzantines, Alexandre deviont à la fois symbole de l'éphémère a de l'homme juste dont l'âme, à l'heure du trépas, est regue par l'archange Michel. Son clevation au Panalis est le thème des legendes que lon

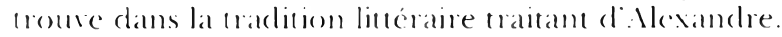

Alexander's campaign against the Persians revived bitter memories in the minds of the Greeks. These memories probably prompted the architect Deinocrates (or Stasicrates) to propose to Alexander the creation of the cighth wonder of

\footnotetext{
* This study was originally prescmed as a lecture at the Alexander Simposium at lase Royal (Ontario Muscum, Ioronto, on 7 May 1983. It is printed here in a revised form. I one sincere thanks 10 Professor Neda I.cipen, loromto, who was the soul of the Alexander Symposium, and Professor Rigas Bertos, Montreal. for his patience in listching. For photographs, I am indcloted to Professor Kurt Weitmann. Princeton. X.J.; Dr. Vera Zalesskaya. Lemingrad: 1)r. Aimilia (Feroulanou. Athens; and I)r Sotcrios kadas. Thessaloniki, who went to . Mt. Athos especially to photograph the momuments reproduced here for me.
}

the world: a colossal figure of the world conqueror carved out of the marble rock of Mt. Athos - the rock Poseidon hurled at one of the giants when they warred against the gods. The young king was to be represented holding a city in his left hand and "with his right should pour forth a river running with roaring water into the sea." Alexander did not approve of the proposal, and his image was never carved on Mt. Athos. ${ }^{2}$ However, it was des-

1 Plutarch, Alexander, 1.xxu, 3-4, in Lives, The I.coll Classical library (Londen and New York, 1919), vis, 421, 127. The incident was also reported earlier by Suabo, Book xvi, (h. 1:23, ed. 1. Mcincke (Leiprig. 1853), m. 894.

2) Cif. S. Kadas, To Ilagion ()ros (Athens, 1980)). 9. I atcr artists were fascinated by this daring project and imagined the heroic or divine colossus in different wass. as cxcmplified 
tined to be represented on the walls of the monasteries established by Byzantine monks on that same mountain, when it became the garden of the Virgin Mary. This Christian image grew out of meditations on Alexander's destiny by Church Fathers, monks, emperors, poets, and artists. It evolved from earlier Byzantine images of Alexander that must be discussed first (Fig. 1).

In the formative years of the Byzantine Empire, the Hellenistic tradition that related Alexander to the gods died out. Among the last manilestations of this concept were a golden plate from Abukir (fourth or fifth century) and a relief from Messeni (fourth century), now in the Lourre, which represents Alexander with the lion skin of Heracles. ${ }^{3}$ The Eastern Christian artists were enchanted by Alexander the great hunter-warrior-ruler - the ideal prince who chases wild animals, mostly lions, for the benefit of his people. In this image one sees the continuity of a notion of kingship that can be traced as far back as the Assyrian kings. The royal hunt has always been considered symbolic of transcendent victory, of the triumph of good over evil. In accordance with this tradition many hunting scenes in late antique and early Christian times have been interpreted as evocations of Alexander the victor. He is represented as the ideal hunter as late as the seventh century in a fragment of an Egyptian textile, now in Washington, D.C. (Fig. 5). ${ }^{4}$ The fragment contains (wo) mirror

by a drawing by Pietro da cortona made in the midseventeenth century to honour Pope Alexander v $11, n o w$ in the British Museum, and a 1721 engraving by Joham Fischer von Erlach. in the Sational liblativ of Vicmmal (IFig. 4) (X. Yalouris, "Alexander and Mis Herilage," Th" search for Alexander. An lixhibition [Xew York. 1980)]. 10-20. esp. 14-19, fig. 9: P. Huber, Athos, Leden. (;iaube. kimst. 3rd ed. [\%urich and freiburg im Br., 1982)]. ligs. 2) $3)$.

3 A. Alföldi, Die Kontormiaten (Budapest, 1993), 14, 85-58 102-103; A. and F. Allöldi. Die Kontorniut-Medallions. Antike Mümzen und (jeschminene Steme, $\%$, l (Berlin. 1976): Roval Ontario Muscum, The Search for Alexander. Supplement to the Catalogue (Ioromto, 1983), 35. S-50) . M. C. Ross, "Notes on Bryantine Gold- and Silversmith's Work,"

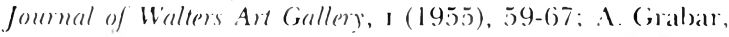

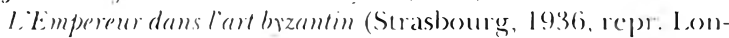
(lon, 1971), 93ff.; 1t. J. (Bleixner, "Alexander der (;osse," Recollexihon zur byzantinischen Kunst (Stullgart, I96(i) , I, cols. 96-99: H. J. Gleixner, Das Alexanderbild der Byzantiner, diss. Munich, 1961, a very important study wilh (mp)hasis on literary sources. I am indebted to Prof Marcell Restleof the University of Munich whe made this work arailable to me. See also F. Pfister. Alexander der Grosse in der byzantinischen Literatur. und in nemgriechischen Volksbürhern. Probleme der neugriechischen Literatur, m (Berlin, I96()); (f. M. Bicherr, Alexander the Great in Greek and Roman Art (Chicago), 1964).

4 K. Weitzmann, ed., The Age of Sprimulity, Latte Anrique and Early Christian Ant Third to the S(remth (ientury, Catalogue of an Exhibition at the Metropolitan Musemm of Art, orember 1977-Februar 1978 (New York, 1979), 91. 92 no. 81 : of. 89 no. 79. images depicting "Alexander the Macedonian," as a Greek inscription attests, on cither side of the Tree of Life which indicates the symbolic maning of the hunt. The theme contimues throughout Byzantine art. However, much of the concept of the perfect prince adorned with Aristotle's "megalopsychia," embodied in the person of Alexander, passed on to the Byzantine Emperor who became the hero and the symbolic hunter."

The image of the hero was a powerful one in ancient Greek culture. From Heracles to Achilles and finally to Alexander, heroism was trumpeted and made public. In the Christian world in general, and in Byzantium in particular, the emphasis, on the other hand, was placed on the martyr. Martyrs' deeds tended not to be revealed; there was only the fact of their sacrifice. And yet in the hero there was the element of the martyr to whom Alexander was to be related. Farly Church lathers compared Alexander the hero io the herocs of faith. John Chrysostom, for example, said of Alexander that virtuous and great as he had been, he was not like the martyrs of faith. ${ }^{6}$ But the people, the scribes, and poets who produced the different verse and prose versions of Alexander's romanticized deeds did see him as a martyr. John Chrysostom wrote that in his time people allached Alexander's coins to their heads and feer. ${ }^{\top}$ As late as the early ninetecnth conturv, whon Dodwell visited Greece, he mentioned that it was customary for women to wear coins of Alexander the Great as amulets. ${ }^{8}$ Alexander's early "unjust" death, at a time when it secmed nothing could stop) him from achieving his heart's clesire, led o his being viewed as a martyr. This is indicated, for cxample, in the narration of Alexander's testament and death in at least one of the versions of the late of Mlcxander."

His personalits. exuberant nature, romantic beauty, generosity, and carly death conchanted writers. poets. and artists who wore Alcxander's cloak, and all these characteristics were often cited in the titles of manuscripts containing Alexander's saga." They contributed to the cration of his various images that appeared in Byantium, parallel to one another or even woren togenher: the idcal prince-emperor. Whe hero for whom the carth was not enough, the (hristian martyr whom

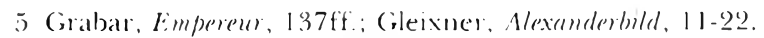

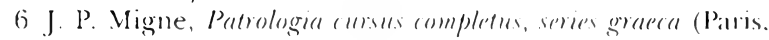
$1857-66)$. 1.x1. cols. 581-82. Henceforeh Pa;

7 PG . xi, col. 2240.

8 Cited by Ph. Koukoulès, Byzantimon bios han politismos, fo vols (Athens, 1948-5j), vi, 265.

9 D. Holom, The Tale of Alexander. The Rhymed Version. Byantine kat Veocllenike Biblionlacke. I (lhessaloniki. 1974), 176ft. ㄴ. 268011. 2770ff. 282361.
}

10 G. Wagner. Carmina graeca medii areil (L ceip)rig. 187.1), ix-x. 
the people wished to see resting in the green pastures of the redeemed. ${ }^{11}$

The Alexander Romance is generally known under the name of pseudo-Callisthenes, but in fact it has no connection with the historian Callisthenes of Olynthus who accompanied Alexander on his expedition. The source of this mistaken attribution is to be found in the titles of several manuscripts. ${ }^{12}$ Regardless of its authorship and sources, this romance was one of the Byzantines' most beloved readings. From the fifth century on, it underwent numerous revisions and adaptations. Their authors used the material rather freely, so that the various versions differ greatly. ${ }^{13}$ A Greek version of the Romance in verse appears for the first time in 1388 in cod. Venice, Marciana 408. ${ }^{14}$ In addition there exists another, post-Byzantine version in prose to which the modern Greek rendering, the so-called Phyllada tou Megalexandrou, is related. It was published for the first time in Venice in 1680 and has been reissued several times since then. ${ }^{15}$. Finally, there is a rhymed version, illustrated with woodcuts, which originated in Zakynthos shortly after $1500 .^{16}$

11 Despite major works by philologists on various problems (contributions made by Greek scholars are of special significance), a complete, systematic study of all these aspects of Alexander's image in Byzantium and modern (ircece considering the evidence of both texts and images has not as yet appeared. For the image of Alexander in the West see G. Cary, The Medieval Alexander (Cambridge, 1956; repr. 1967), and for more recent bibliography, especially on the legend of Alexander, C. Frugoni, La fortuna di Alessandro Magno dall'antichità al Medioevo (Florence, 1978).

12 D. J. A. Ross, Alexander Historiatus: A Guide to Medieval Illustrated Alexander Literature, Warburg Institute Surveys, I (London, 1963), 5 and n. 2.

13 For the textual problems, dates, and relations of extant manuscripts and proposed theorics in general sce R. Merkelbach, Die Quellen des griechischen Alexander-roman (Munich, 1954); Pfister, Alexander; Gleixner, Alexanderbild, $61 \mathrm{ff}$; for the modern Greek versions see G. Veloudis, Der neugriechische Alexander Tradition in Bewahrung und Wandel (Munich, 1968). For a brief presentation of the various problems and more complete bibliography see D. Holton, He Hellenike paradosi tou mythistorematos tou Megalou Alexandrou, Keimena kai Meletai Neoellenikes Philologias, ed. G. \%oras, Lxxxı (Athens, 1973), and also TusculumLexikon, 3rd ed. (Munich and Zurich, 1983), 35-37 with bibliography. The exact nature of the "versions" is a subject of discussion among philologists. The question is whether there are indeed versions of the Romance or groups of texts (Textgruppen) that present similarities among themselves. The latter view is supported by Veloudis, Alexander Tradition, 20-21.

14 For the latest edition see S. Reichmann, Der byzantinische Alexander-gedicht nach dem cod. Marcianus 408, Beiträge $z$. klass. Philologie, xi11 (Meisenheim am Glan, 1963).

15 K. Mitsakis, Der byzantinische Alexander-roman nach dem cod. Vindob. theol. gr. 244, Miscell. By7. Monascenia, vII (Munich, 1967), K. Mitsakis, "Diegesis peri tou Alexandrou," Byzantinisch-Neugriechische Jahrbücher, xx (1970), 228-301.

16 Holton, Tale of Alexander, with an excellent introduction.
Among the extant Eastern manuscripts, there are a number with illustrations: two Greek codices of the thirteenth and fourteenth centuries (one in Oxford, Bodl. Lib. cod. Barocci 17, with muchflaked miniatures, and the other in the Hellenic Institute in Venice with a series of important fullpage illustrations), two Serbian manuscripts of the fourteenth and fifteenth centuries in Belgrade and Sofia respectively, ${ }^{17}$ and several Armenian codices with dates ranging from the thirteenth to the eighteenth centuries. ${ }^{18}$ All these codices, although late in date, have a common root in an early Greek model. Illustrations made for the Romance, however, are also found in other types of manuscripts, such as hunting treatises. Thus, the tenth-century Cynegetika of pseudo-Oppian (now in Venice, Bibl. Marciana cod. gr. 479) includes three scenes stemming from the Romance, depicting Alexander bringing Bucephalus to Philip, Bucephalus imprisoned behind iron bars (on the upper part of the miniature), and Alexander chasing Darius (Fig. 6). ${ }^{19}$

Of the preserved complete illustrated manuscripts, the most precious is the one in the Hellenic Institute in Venice. ${ }^{20}$ Xyngopoulos, who first published the manuscript fully, tentatively assigned it to Crete and the fourteenth century. When Gal-

17 V. R. Pctković, "Le Roman d'Alexandre illustré de la Bibl. Nat. de Beograd," Studi bizantini e neoellenici, vi (1940), $34 \mathrm{lff}$ and pls. xciv-cirr; A. Grabar, Recherches sur les influences orientales dans l'art balkanique (Paris, 1928), 108 and pls. XII-Xvi (miniatures of the manuscript in Sofia no. 771 [381]; K. Weitzmann, Greek Mythology in Byzantine Art, 2nd ed. (Princeton, 1984), 104; Holton, Paradosi, 22-23.

18 A list of the most important illustrated Armenian manuscripts and bibliography is in Weitzmann, Mythology, 104, to which the following should be added: P. N. Akinian, "Die Handschriftliche Überlieferung der armenischen Übersetzung des Alexanderromans von Pseudo-Kallisthenes," Byzantion, xill (1938), 201-206, and the more recent A. M. Wolohojian, The Romance of Alexander the Great by PseudoCallisthenes (New York and London, 1969). Among the richest extant illustrated Armenian manuscripts are Venice, San Lazaro, cod. 424, thirteenth or fourteenth century, in F. Macler, L'enluminure arménienne profane (Paris, 1928), 21 , pls. 1-XIV; Vienna, Mechitarist-Congregation, cod. 319, from 1694, most recently in Heide and Helmut Buschhausen, Armenische Handschriften der MechitharistenCongregation in Wien, 2nd ed. (Vienna, 1981), 169f., no. 37; and Paris, Bibl. Nat., cod. arm. 291, from 1712, in Macler, Enluminure, 26, pls. xLvi-Lix. Special mention should also be made of cod. Jerusalem, Armenian Patriarchate, MS 47.3 from 1536, in N. Bogasian, Grand Catalogue of St. James' Manuscripts, 7 vols. (Jerusalem, 1966-77), II, 460-66, figs. 24-26, and B. Narkiss, ed., Armenian Art Treasures of Jerusalem (London, 1980), 92.

19 Weitzmann, Mythology, 104ff., 118, and figs. 108-109.

20 A. Xyngopoulos, Les Miniatures du roman d'Alexandre le Grand dans le codex de l'institut hellénique de Venise (Athens and Venice, 1966), a complete publication with several reproductions in colour; I. Gallagher, "The Alexander Romance in the Hellenic Institute at Venice: Some Notes on the Initial Miniature," Thesaurismata, xvi (1979), 170-207. 
lagher subsequently discussed the manuscript's textual problems, picture cycles, relatives, and other related questions, he suggested that it was a product of the Empire of Trebizond, commissioned by a member of the ruling dynasty, the Grand Comneni, most likely in the second half of the fourteenth century. Its miniatures show how artists conceived Alexander, for they were the ones who in essence interpreted the legend dclivered to them by writers and poets, constantly adapting their illustrations to the changes madc in the text itself. However, they never broke the pictorial tradition they inherited from the Hellenistic period. In turn, writers, poets, and illustrators all responded to the demands of the people who perpetuated Alexander's images in their oral tradition.

The identity of the emperor represented in the title miniature, fol. $1 \mathrm{r}$, has been disputed (Fig. 7). Xyngopoulos saw it as a portrait of Alexander, while Gallagher suggested it was a portrait of the ruler who had commissioned the manuscript. It is immaterial for this discussion which one of the two views is more likelv correct, because in the illustrations of the text the image of Alexander is that of a contemporary Palaeologan emperor. Although Christian insignia have been avoided whencver possible, the crossform of the prependulia has been retained in proper Byzantine fashion. ${ }^{21}$ By such means the illustrator suggests a Christianization of Alexander's image. Occasionally, as Gleixner has observed, Alexander wears a starry garment, which transforms him into a cosmocrator.

This Christianization takes another form in the story of Alexander's visit to Kandaki, the queen of the Ethiopians. The queen places a panel portrait of Alexander, which a painter has secretly produced, in a chest as a holy relic (Fig. 8) ${ }^{22}$ Furthermore, throughout the illustrations the artist has extended this rendering - consciously I believeto representations of statues of kings or other persons that take the form of icons or panels enclosed in frames. However conventional this system may be, it reflects a desire to Christianize the heroes of the Romance and to turn away from constant pictorial references to the pagan past.

Apart from the Romance, in the epic poem Digenes Akritas, the story of Basil Twyborn Borderer, probably written in the eleventh century, there are very interesting echoes of the Alexander theme-in fact textual interpolations from the pseudo-Callisthenes Romance, intended to create a

21 See, for example, fols. 44r, 52v, 53v, ctc., Xyngopoulos, Miniatures, pls. xxv, 51; xxx, 62; xxxı, 63; Gleixner, Alexanderbild, 123.

22 For a colour reproduction see Xyngopoulos, Miniatures, pl. $\mathrm{x}$. parallel between the hero Digenes and Alexander. ${ }^{23}$ In this epic, Alexander retains the image of the legendary hero to whom Digenes aspires. But there is something more: in the fabulous mosaic of the imaginary palace of Digenes, amidst the wondrous paradise, painted fair in gold mosaic, are the triumphs of $\Lambda$ lexander "the wise." He is placed next to the heroes of antiquity on the one hand and the heroes of the Old Testament on the other. Next to him stand Samson, Moses, and Joshua. ${ }^{24} \mathrm{~A}$ visual relative of this literary image is a silver bowl of the twelfth century, now in Leningrad, where Alexander ascending into the heavens is related to Samson (Fig. 9). ${ }^{25}$ The pocm and the bowl represent another attempt to bring Alexander into the world of the heroes of the Christian God.

This "sanctification" of Alexander occurred much earlier in exegetical literature - expositions of the holy books written by Church Fathers - for he had already cntered the prophetic books of the peoples with whom he had come into contact. ${ }^{26}$ Of special interest is the commentary of the Book of Daniel and its illustrations. Daniel, whose grave was in the city of Susa (where one of the instances of Alexander's deification occurred), presents two allegories (7:1-28; cf. also 2:31 f.). In one of them he describes four beasts. The first two were interpreted as images of the kingdoms of the Babylonians (Nabuchodonosor) and the Persians (Darius), while the fourth one was seen as an image of the Roman Empire (Augustus). The Church Fathers interpreted the third of these beasts, resembling a winged leopard, as an image of Alexander the conqueror, who destroys the Persian Empire in accordance with the plan of God. ${ }^{2 i}$ The illustrators followed this interpretation and identified the beasts accordingly, as a miniature from the Christian Topography of Cosmas Indicopleustes show's. Although the illustration (Fig. 10) belongs to an eleventh-century copy now in the monastery of St. Catherine on Mt. Sinai, cod. 1186, the archetype of the Topography was written in Alexandria in the sixth century and was illustrated in the same area. ${ }^{28}$ Alexander "the

23 For a discussion of these parallcls see Veloudis, Tradition.

24 J. Mavrogordato, ed. and trans., Digenes Akrites (Oxford, 1956), 219, 221, 223, vv. 3350-3409.

25 C. Settis-Frugoni, Historia Alexandri elevati per griphos ad aerem. Istituto storico Italiano per il medioeveo, Studi storici, Fasc. 80-82 (Rome, 1973), 174ff.; Iskusstvo Vizantij v sobranija SSSR, lixhibition Catalogue, Leningrad, 3 vols (Moscow, 1977), II, 83, no. 553, with more complete bibliography.

26 Glcixner, Alexanderbild, $52 \mathrm{ff}$. with earlier references.

27 John Chrysostom was one of the early Fathers who proposed such an interpretation, $P G$, Lxxxi, col. 1417; Gleixner, Alexanderbild, 54-55; cf. also Cary, Medieval Alexander, 120.

28 For a general discussion of the codex see P. Huber, Heilige 
Macedon," represented in the guise of a Byzantinc emperor, is part of the prophetic vision and an instrument of the plan of God. This interpretation can be related to the Byzantine imperial ideology-the kalos basileus who is protected by the Lord and is led by him to victory. However, Alexander's position within God's plan acquires another climension in the course of the iconographic development of this vision of Daniel in Byrantine art. Developed into an independent iconographic theme, it found a place in the Painter's Manual by Dionysius of Fourna, and because it refers (o) the Last Day (esp. Daniel 7:9f.), it was included in representations of the Last Judgment in both frescoes and icons. ${ }^{29}$ Thus, Alexander's image, placed among the other three kings of the ancient world, was given an eschatological meaning.

From the pictorial cycle of the Alexander Romance, artists greatly favoured the Ascension or Ascent of Alexander. It has becn ascertained that many Byantine representations of the subject had an influence on Western art, through the presence of (ireck artists who worked in the West, through the circulation of minor works of art. mostly ivories and textiles, or even directly through an illustrated pseudo-( Callisthenes manuscript that may have entered western Europe via southern Italy: ${ }^{30}$ Although textual versions of the story varr, its nucleus remains the same. ${ }^{31}$ This is also truc for the representations, which in the East repeat the basic rendering of the theme, as can be seen by comparing a fourteenth-century relief from Mistras to three earlier examples: ${ }^{32}$ a ninthor tenth-century ivory, now in Darmstadt; the well-known twelfth-or thirteconth-century relief on the church of San Marco in Venice; and a thirteenth-contury textile from Regensburg, now in Berlin, dependent on Byantine prototypes (Figs. 11-12).33

Berge, $18 \mathrm{ft}$; for its complete illustration sec $\mathrm{k}$. Weitmamn and (; Calaratris, A Catalogue of the Illustrated Manuscripts in Si. (ialherime's Monastery on Mi. Sinal (forthcomning).

29 Sec A. Xyngopoulos, Mouseion Benaki, Katalogos ton Eikonon (Alhens, I936(j), 54-5j, for examples and references; and II. Chatridakis. Icônes de Samb-Cirorges des Grecs et de la Collecleon de l'Institul Hellénique de Venise" (Venice, 1962), 88-89.

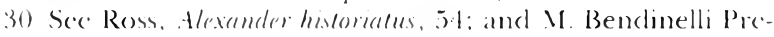

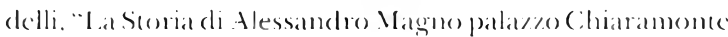

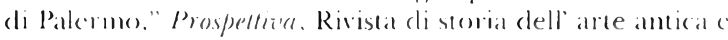
mederna, no, $4(5$, oflprint (1986), 1,3-2) I.

31 Forabriclacount sec Yalouris, "Alexander and His Herilage," 16.

32 The relief, first published by $\mathrm{A}$. Orlandos, was part of the cxhibition The Search for Alexander, 190, 191c

33 Reproduced and discussed in Setuis-Fugoni's excellent study Ihistorin Alexandr, which deals with the textual and pictorial transmutations of the theme. New material is presented in a forthcoming article by (h. Bouras in Deltion Christankis Archaeologikis Hetaireias (1989)
Any discussion of the iconography of the scene must take into account-among other related themes - the representation of the Ascension of the Prophet Elijah. In many instances the scene depicts the fiery chariot heraldically arranged in the manner of the rendering of Alexander's Ascension. ${ }^{34}$ A seventeenth-century Greek icon, for example, can clemonstrate the compositional affinity of the two themes (Fig. 13). The relationship is not accidental and does not pertain to forms only, but exists in various ways in the Alexander saga. For instance, in the Ethiopian Christian Romance of Alexander, he is considered a companion of Elijah. ${ }^{35}$ For the Byrantines, howerer, the prophet of the fiery chariot was closely related (o) the cult of Apollo-Itelios. That is why Elijah's chapels were always erected on top of hills and mountains. In the mind of the artist who used Alexander's Ascension as a model for the Ascent of Elijah, Alexander continued to be associated with a solar divinity.

The Ascension or the Exploration of the Heavens by Alexander has a symbolic meaning. In its nucleus, the story can be traced back to very carly sources such as the legend of Etana, the old Babylonian deified king of the first dynasty of Kish in the third millennium B.C.., who flies to hearen because he wishes to obtain immortality. Representations of the erent occur in Aktadian seals, (at. 2350. ${ }^{36}$ the search for immortalits is not stated in the Alexander legend; the meaning of this search is too manifold to be discussed here. It is only possible to poim out that its pictorial rendering is closely related to imperial images representing the triumph of the emperor riding his chariot or quadriga and that, in general, the composition can be considered an image of triumph and glors. The relation of such imperial images to the Ascension can be demonstrated br comparing the Darmstadt ivory, referred to earlier, to a fourth-century medallion of Constantius in (Figs. 11 and 14). Similarities include the raised right hand, a sign of the cosmocrator, and the globe held in the left hand. ${ }^{3 i}$ The triumphal meaning of the Ascension is further suggested by the quadriga of the sun and even by the heraldic arrangement of the griffins indicating a "master of animals." 36

3.1 See O. Demus, "Elijah and Alexander," in Studies in Memon' of Darid Talbot Rue, ed. G. Robertson and (;. Ilenderson (Edinburgh, 1975), 64-67; ch. also G. Galavaris, The Icon in the Life of the Church. Iconography of Religions, xxiv, 8, Institute of Religious Iconography, University of Groningen (Leiden, 1981). pl. x, c.b.

35 E. A. Thompson Wallis Budge, The Alexander Book in Ethiopia (London, 1933), 236-37

36 Cif. also "The Flight of Cilgamesh," in Settis-lirugoni, Historia Alexandri, 48-49, fig. 9.

37 Settis-Frugoni, Historia Alexandri, 96, 183-84.

38 For a full discussion of the meaning of the griffins in 
On the whole, the Latin West interpreted the Ascension in a negative way. Through this celestial journey Alexander is seen as an Antichrist. No man may ascend to heaven who has not deserved to do so by good works. ${ }^{39}$ On the contrary, the Christian kast saw the legend in a positive light only. The world is not enough for the hero who desires to penetrate the secrets of the cosmos. The heavens bclong to him too. But by exploring the heavens, the Christian hero realizes the limitations of his glory before the glory of (iod.

In the thirteenth century, when a new wave of humanism invaded the spirit of Byzantium and the political strength and glory of the Empire waned, a spirit of pessimism and melancholy was introduced into literature and art. A special type of religious poetry was created, written in the koine, the language of the people, dealing with the transience of earthly existence. Although it has been suggested that one of the earliest works of this genre, A Sinner's Prayer, may have been composed in the welfth century, most known works cannot be dated earlier than the end of the thirteenth century. Among them, An Alphabet of Contrition and Soul-Aiding of the Transience of this World is well known. ${ }^{40}$ Alexander's image came to be associated with this litcrature. It is now that he entered Athos, the Holy Mountain, as captive of death.

Briefly, the story of this new "Alexander Advenme" has been reconstructed as follows: sometime before the year 1484, a certain Sisoes composed a pocm that was a meditation on death over an open grave. ${ }^{41}$ The illustration for the poen was the source of frescoes, painted on the walls of the monasterics, in which the text of the poem was enclosed; its function was to explain the scenc. In the process, the author of the poem was confused with St. Sisoes, the famous anchorite of the Egyptian desert, who was now depicted meditating over the open grave. This phase of the development of the theme is exemplificel, among other represcutations, by a sixteenth-century fresco in the narthex of the catholikon of the Stavroniketa momastery on . Mt. Athos (Fig. 15). But at the beginning of the same century, in a number of the Sisoes compositions, the grave and skeleton were iden-

relation (o) Alexander, see Settis-Frugoni, Historia Alexandri, 209ff.. 331ff.

39 Carr, Medieral Alexander, 134f., 291.

40 In gencral, see K. Kirumbacher, Geschichte der byzantinischen Literatur, 2nd ed. (Munich, 1897), translated into Gicck (Athens, 1964), 822ff: for the text of the Alphabet see Wagner, Carmina Graeca, 242-47.

41 The development of the Sisoes image from the textual and pictorial points of view has been admirably discussed by R. Stichel. Spail-und Nachbizantimischer Vergänglichkeitsdarstellungen, Byantina V'indobbonconsia, v (Vicnna, 1971). 8.tf., 9111.. I00fi. tified with those of Alexander. Thus, he became a component part of a composition whose meaning is the futility of earthly life. This pictorial association of Alexander with images of transience has deeper roots.

In late antique philosophy, Alexander was conceived as equal to all men beforc the face of death. ${ }^{12}$ The Christian Fathers transmitted this thought to the Byzantine world and eventually the idea was introduced into later recensions of the Alexander Romance. For example, Alcxander seeks in vain the Fountain of Life; his Ascension serves to remind him of his humanity. It was only in the twelfth and thirteemh centuries that the Romance was cularged with diclactic reflections on the vanity of human glory and Alexinder was presented as an image ofl Fate to which all people arc subjected.

As a gencral symbol of this transitoriness, an image of the lumman confrontation with the grave. and $n o t$ as an historical image, Alexander was incorporated into the Sisoes compositions in the sixteenth century. At first he is introduced by the name "Alexindros" only, cited near the sarcophagus that contains the skeleton, as seen in a fresco in the monastery of Dionysion on Mt. Athos (Fig. 16a, b) ${ }^{43}$ Somc later repiescontations depicting Alexander nampled by (haron himself should be interpreted in the same spirit, as a symbol of our common human fate. The fact that there are examples-such as an eightecnthcentury fresco in the monastery of (iregoriou on Mt. Athos (Fig. 17) - in which the cowned ligure is not identificd attests to this interpretation. It is the symbol of the mighty and their late. In other instances, however, as in a 1765 liesco in the monastery of Philotheou, M. Athos, I)eath, in the form of a black skeleton, treads on a crowned figure rearing the costume of a Byzantine emperor, identified as "Alexandros," and attacks the figure with his luuge scylhe (Fig. 18). ${ }^{\text {H. }}$

However, as the Sisoes theme was repeated in frescoes and icons, a later monk who could no longer understand the name "Alexandros" at the sarcophagus brought about a change. He qualified "Alexandros" as "the Macedomian" and/or "the King of the Hellenes." Thus the symbol of transicnce became concrete: once more it was the historical Alexander. Another legend was born according to which the anchorite Sisoes discovered Alexander's grave in the desert. Long

42 Marcus Aurclius, among others, provides valuable evidence for this concept. See W. Hoffmann, Das literarische Portrait Alexanders des (irossen in griechisch-rönischen Altertum (Lciprig, 19()7), 80ff: Stichel, Vergänglichkeit, 105-106. 13 Stichel, Vergäinglichkeit, 83, 86, III, fig. II. 44 Stichel, Vergainglichkeil, 11, fig. 5. 
inscriptions accompanying these large compositions - as for example in a 1566 fresco in the monastery of Barlaam at Metcora-refer to the historical Alexander, to the legend, and to the poem of futility (Fig. 19). ${ }^{45}$

And yet the same monks and poets who sang the beauty and the glory of the "Christian" Alexander and meditated on the death of a hero did not wish to see him vanish as dust in a grave. He was not to remain a captive of death. While the Armenian Alexander saga compared Alexander's life to that of Christ $^{46}$ and the Ethiopian Christian Alexander Romance prescnted the hero crying out to God to receive his soul (God granted his request amid thunder and lightning), ${ }^{4 i}$ the Greeks sought the aid of the archangel Michael.

In a number of post-Byzantine Greek iconsmost of them unpublished and found in churches and monasterics on the Greek islands - Michael is depicted in full military armour trampling on a half-naked man who seems to be sleeping. The archangel holds his sword point down in his right hand and lifts up a small feminine figure in swaddling clothes triumphantly in his left. This is the soul he has rescued from the dead man. In some of these icons, the dead man is identified by inscription as King Alexander. ${ }^{48}$ It has been said, and with good reason, that Michael is an angel of death, or that cleath is conceived as an angel and that in representations like that one just described Michael should be seen as a substitute for the ligure of Charon. ${ }^{49}$ In other words, this composi-

45) For the Grock text of this particular inscription and a (jerman translation see Stichel, Vergänglichkeit, 88.

46 Cif. Heide and Helınut Buschhausen, Armenische IIandschriften, 169, no. 37 (cod. 319 dated to 1694).

17 Budge, Ethiopra, 256

18 Chatzidaksi, Icônes, 91. no. 60, pl. 57; Th. Ch. Aliprantis, Thesauroi tis Siphnou (Athens, 1979), 40, no. 20: 43, no. 7: 60f.. no. 11.

49 Stichel, Vergänglichkeit, $37 \mathrm{f}$. tion should be seen as another pictorial version of humanity's common fate, of human transience.

A detailed study of Michael's role at the hour of death, which should consider dogmatic precepts of the Church and certain pictorial themes such as the Death of the Just Man and the Last Judgment, may bring this interpretation into sharper focus. Here it can only be suggested that the personified Death and the archangel Michael should be kept apart. While Charon is the personification of Death who strikes man with his scythe after God's command-a very common concept in folklore-Michael is the angelos psychopompos par excellence. ${ }^{50}$ He comes to receive a person's soul either to rescue it from the demons who sometimes are also depicted near the dying man or to present it to its Judge; in at least one known icon. the dead man is referred to as "mcrciless and unrepentant." In gencral, however, inscriptions on these icons point to the terrible hour of death.

In light of this evidence, it can be suggested that in these icons Alexander stands, on the one hand, as a symbol of humanity's fate, its mortal nature: not even this great king and world conqueror could escape the terrible hour of death; his crown, in some icons fallen off his head, has proved powerless. On the other hand, Alexander mav be seen as the just man whose soul at the hour of his death is being received by the archangel, who will eventually lead it to Paradise. ${ }^{51}$

50 See N. (;. Politis, Neoellenike Mythologia (Athens, 1871; repr 1979), I, 237ff., 302 I.: also A. Rosenberg. lingel und Dämonen (Munich, 1967), 92ff., lolff.

51 The legends of Alexander's arrival in Paradise, the Gates of Eden, found in the litcrary traditions of both liast and West may also be understood as expressions of the wish of their creators to include Alexander among the redeemed. See Cary, Medieval Alexander, 18, 150, 258-59 and passim; also I. J. Kazis. The Book of the (Gests of Alexander of Macedon, A Metric Ilebrew Version of the Alexander Romance (Cambridge, Mass., 1962), 16-17 


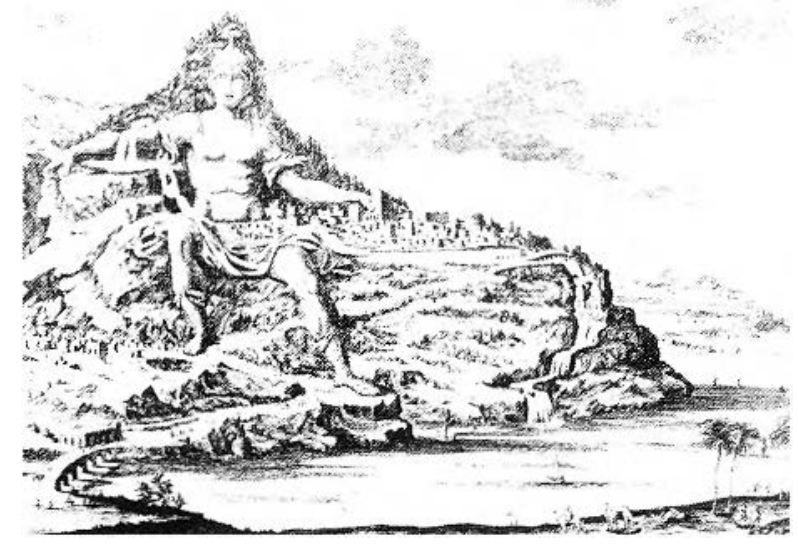

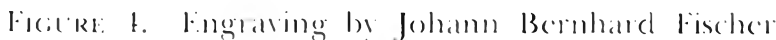

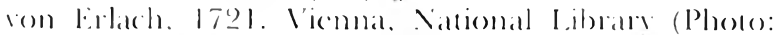

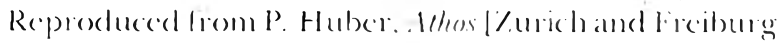
iin $B 1 . .1982)$.

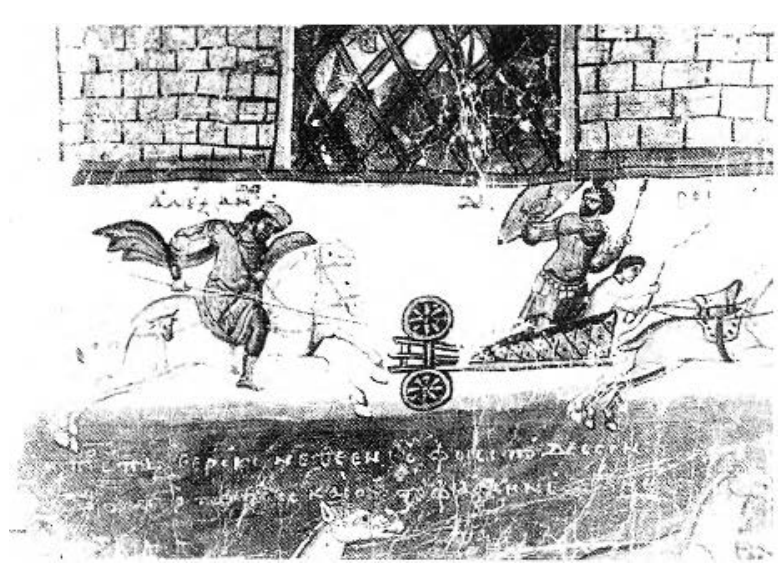

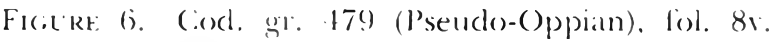
Venice. Bibl. Marciana (Photo: (courtest Professor Kum licit/mamm).

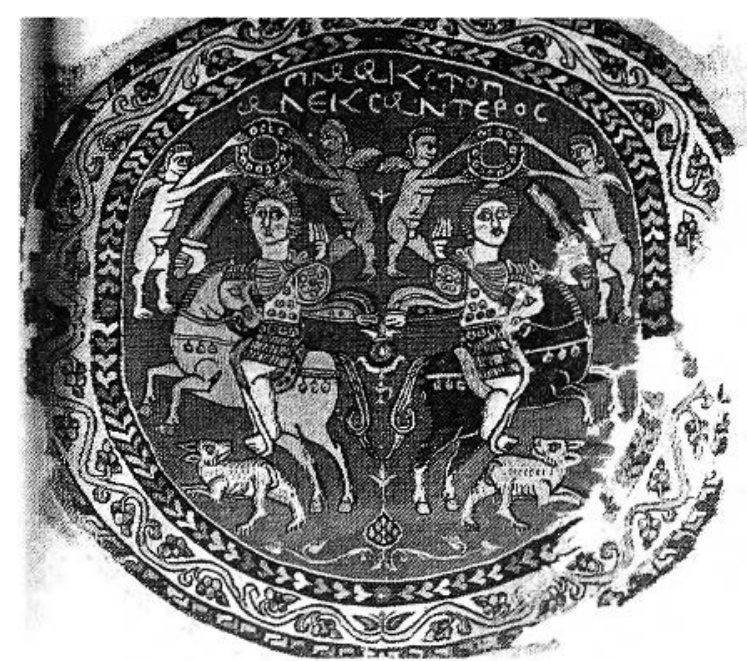

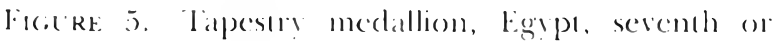
cighth cemtury. Mashington, I).(., lextile Muscum (Photo: Reproduced fiom K. Weitsmamm, edl, The foge

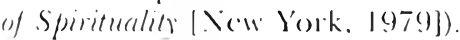

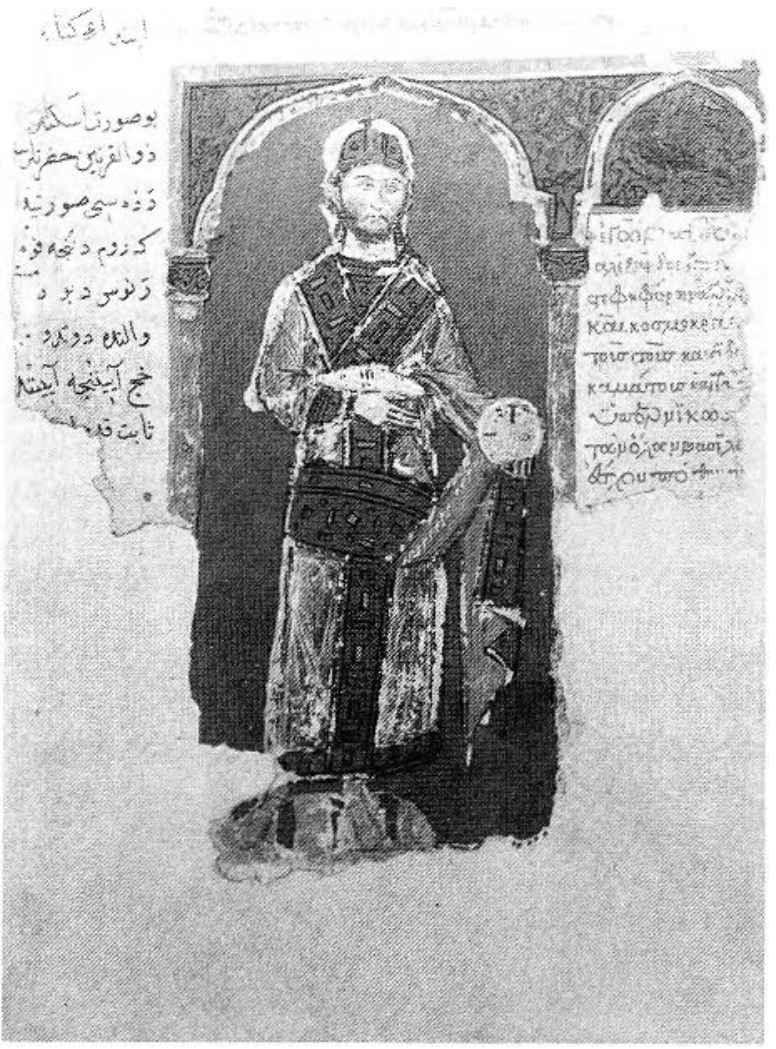

Frotre 7. The Alexander-Romance, fol. lr, fourteconth centur. I'enice. Institut llellénique (Photo: Reproduced fiom A. Xongopontos, Less Miniatures du roman ditlexandere le crand [Ahens and Venice, 1966]). 


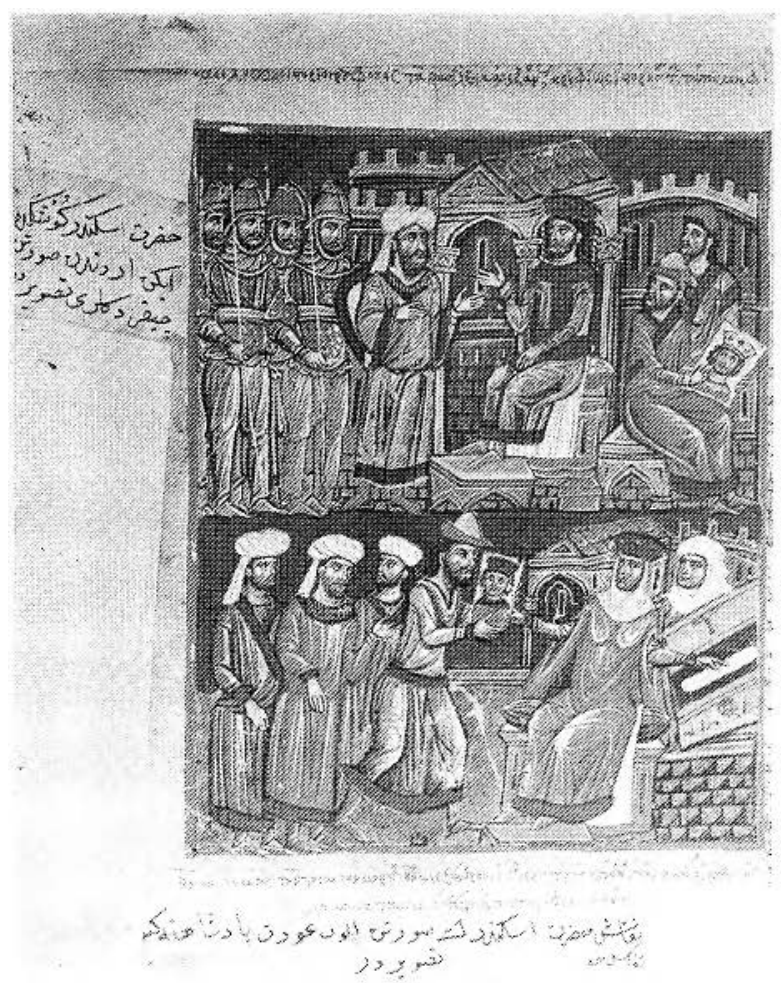

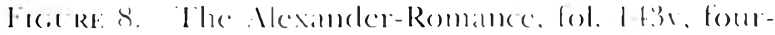

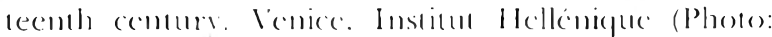

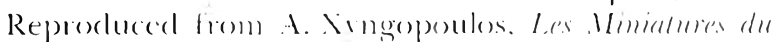

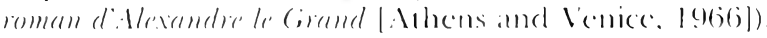

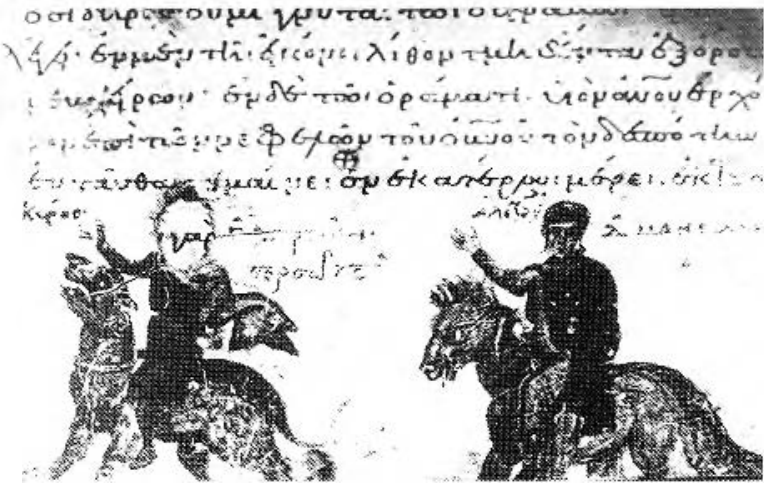

Figlre 10. Codl. gr. 1186, fol. 31r, eleventh centur. Sinai, Monastert of St. Catherine (Photo: Courtesy of the Monasterv).

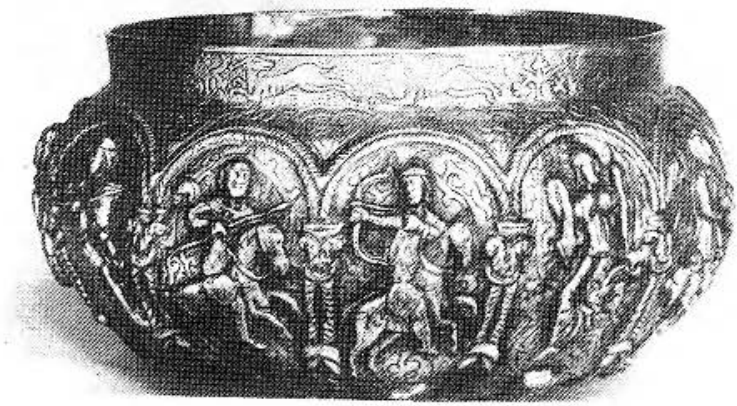

Figure 9. Silver bowl, twelfth century. Leningrad, Hermitage (Photo: Courtesy of the Hermitage Museum, Leningrad).

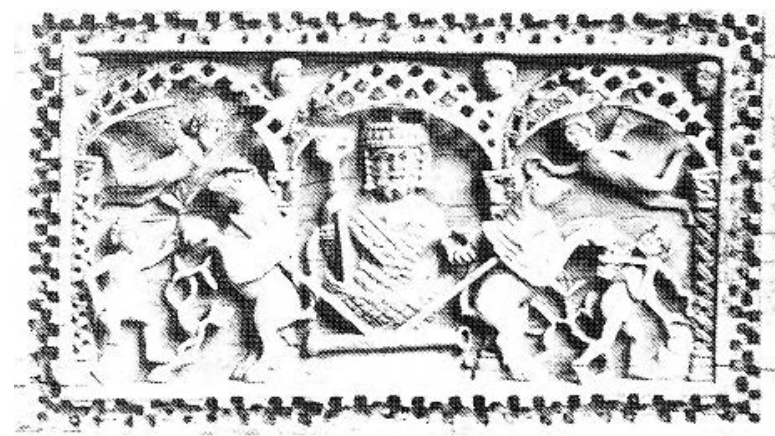

Figi:re 11. Irom box (detail), tenth or eleventh century. Darmstadt, Landesmuseum (Photo: Courtesy Professor Kurt Weitymann). 


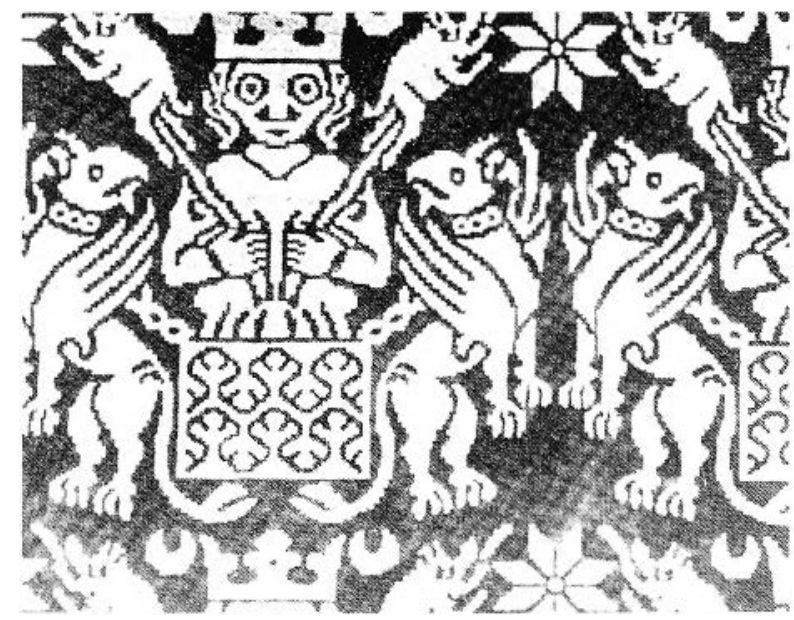

Ficier 12. Textile, thirtcenth century. Berlin, formerly Schlossmuscum (Photo: Reproduced from (. Settis-Frugoni, Historia Alexandri elerati per griphos ad arem [Rome, 1973]).

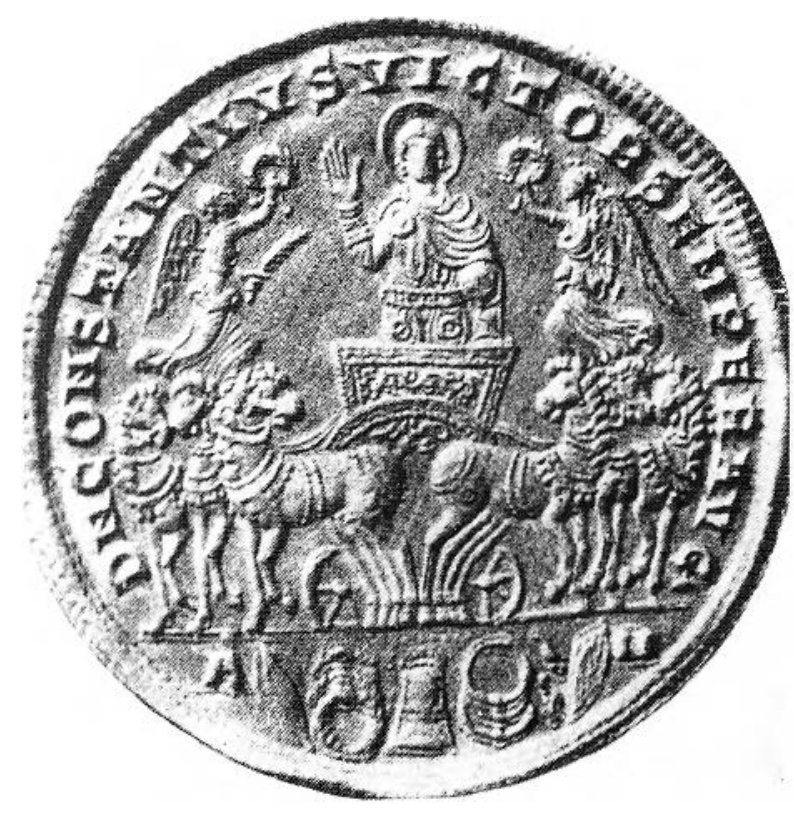

FIolRe 14. Medallion of Constantius II, fourth cenrury (Photo: Reproduced from (:. Sellis-Frugoni, Hiscoria Alexandri elevali per griphos ad aerem [Rome, 1973]).

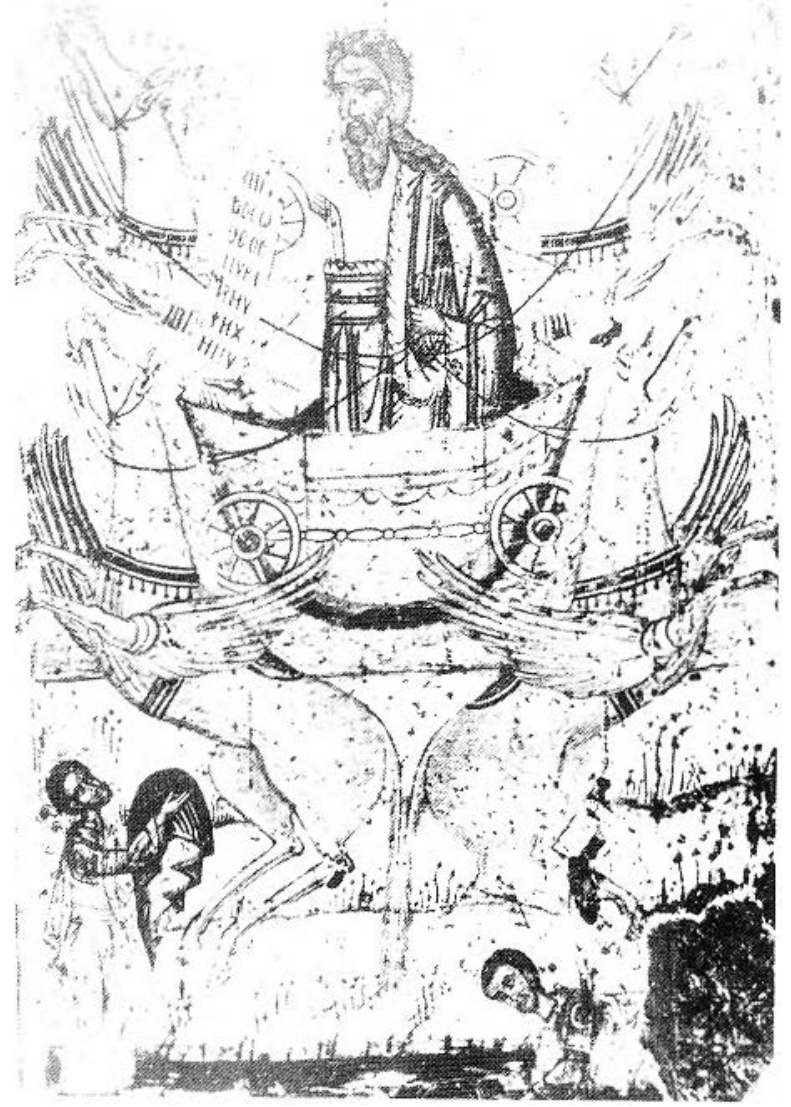

Ficore: 13. (ireek icon, 1655. Kolliken, Switzerland (Photo: Reproduced from G. Robertson and G. Henderson, eds., Studies in Memory of Darid Talbot Rice [lidinburgh. 1975]).

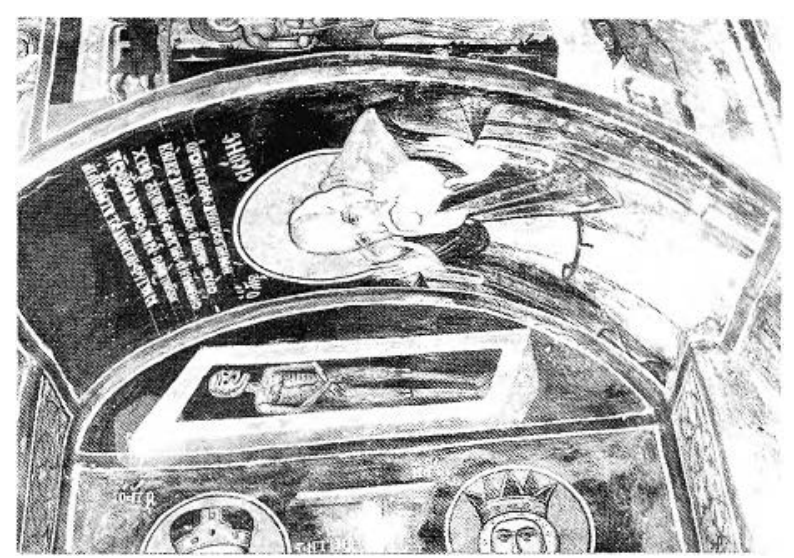

Ficile 15. Fesco, 1546. Athos, Monastery of Sialronikcta (Photo: Courtesv Dr. Soterios Kadas). 

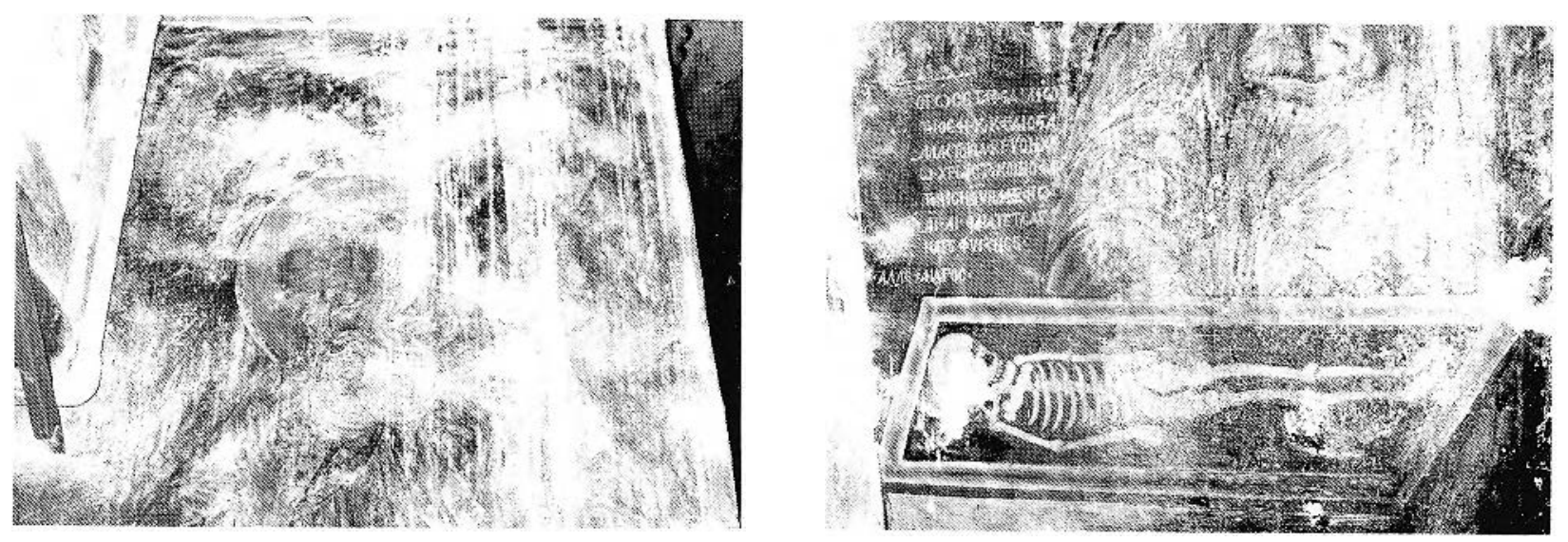

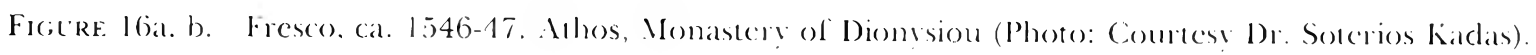

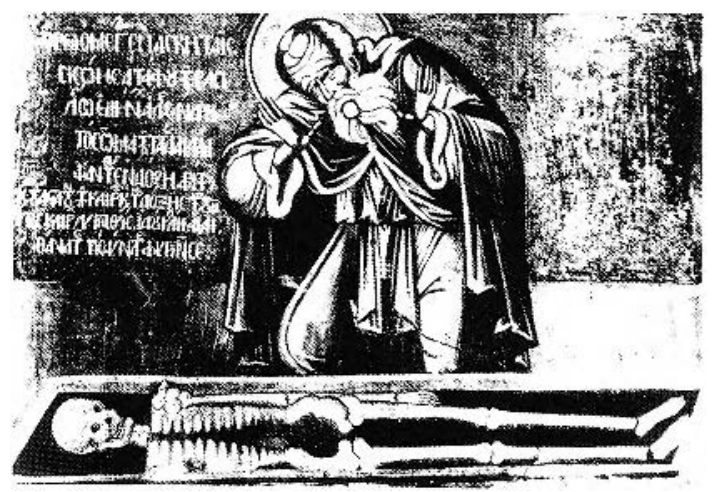

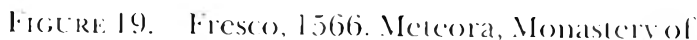
Bartitam (Photo: Reproduced liom R. Stichel, Speil-

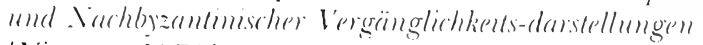

|Viemna, i971]).

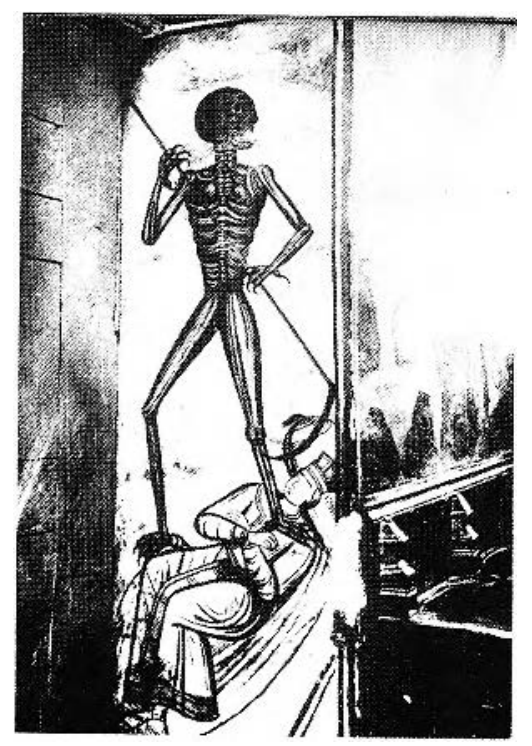

Figere: 17. Fresco, eighteenth contury. Alhos, Monastery of Gicegoriou (Photo: Courtesy Museum Benaki, Allons).

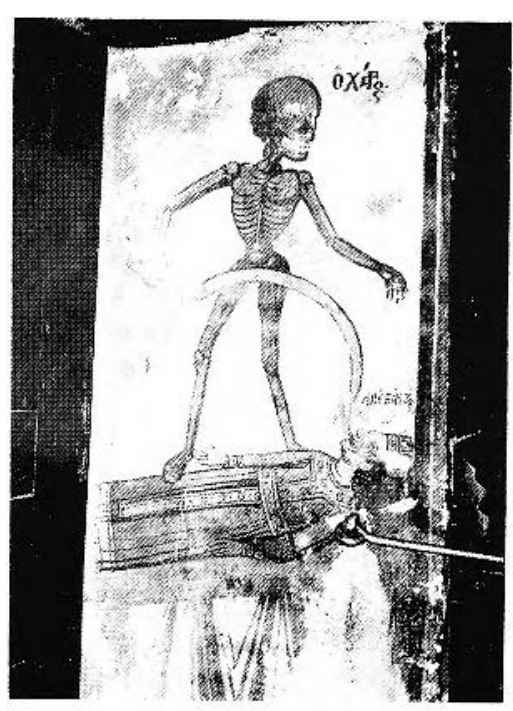

Figurf. 18. Fresco, 1765. Athos, Monastery of Philotheou (Photo: (onutess 1)r. Sotcrios Kadass). 